\title{
REPERCUSSION OF NEEM OIL \& PALM OIL BIODIESEL BLENDS (B5 \& B10) AND DIETHYL ETHER \& 1-BUTANOL WITH PALM OIL BIODIESEL BLENDS ON PERFORMANCE OF A UNMODIFIED DIESEL ENGINE
}

\author{
ABHISHEK SAMANTA ${ }^{1}$ \& PROKASH C. ROY ${ }^{2}$ \\ ${ }^{I}$ Ranaghat Government Polytechnic, Ranaghat, Nadia, India \\ ${ }^{2}$ Jadavpur University, Kolkata, India
}

\begin{abstract}
The biodiesel from inedible Neem oil (NOME; neem oil methyl ester), and edible Palm oil (POME; palm oil methyl ester) taken from economical feedstock be contemplated as less emission producing renewable fuel in current energy resource crisis situation. In this study methyl ester from neem \& palm vegetable oil were produced in an experimental set-up and tested for relevant prerequisite as engine fuel (ASTMD6751 \& EN14214). This study explored the repercussion of neem oil \& palm oil biodiesel blends (B5 \& B10) on direct injection compression ignition engine performance against petroleum diesel. Also addition of additives, Diethyl ether and 1-Butanol with palm oil biodiesel blends were empirically inspected for changes in performance. The engine was loaded and paired with a dynamometer (TMEC10, eddy current). The empirical reactions indicated that against petroleum diesel the numerous biodiesel blends display no compelling advances in engine performance in high load circumstances even with additives. But in low load conditions the engine performance outcome in term of BTE (brake thermal efficiency) indicated that NOME \& POME blends (B5 \& B10) could successfully be adopted in conventional diesel engine.

KEYWORDS: Biodiesel Production, Biodiesel Performance, Biodiesel Engine, Diethyl Ether \& 1-Butanol
\end{abstract}

Received: Jun 06, 2020; Accepted: Jun 26, 2020; Published: Jun 30, 2020; Paper Id.: IJMPERDJUN2020152

\section{INTRODUCTION}

Rapid utilization of diesel roots the rise in urging of energy and simultaneously urgent research work is needed to find suitable alternate bio fuels for unaltered diesel engine. Despite the fact that it had been exhibited that on groundnut oil engine could run, biodiesel can't replace the fossil fuel though the price per barrel to hit the modern highest record. Compelling need is generated to asset an energy resource that is reliable \& renewable but clean and practically feasible. Biodiesel had been designed as the leading successor for unaltered diesel engine. Biodiesels are being regarded as a feasible fuel for the burden about global pollution [1]. Esterifies biodiesel is mono-alkyl-ester also it forms a blend with normal diesel and has low exhaust emissions [2] Limited inclusion of biodiesel, about $20 \%$ with diesel (B20), reduces 20\% hydrocarbon emissions and 13\% CO emissions [3]. Slight NOx emission reductions have been noticed at minor loads and low engine rpm [4] Employing transesterification process viscosity reduces and enhances the other characteristics [5]. Two different alternatives were recommended in recent literature, adoption of liquid-enzyme and uses of immobilized-enzyme to optimized and make cost effective transesterification process [6] although enzymes are cost effective than chemical catalysts. Various researches argue that the biodiesel yielding price was predicted to be in the spectrum 0.90- $1.85 \mathrm{US} \$ / \mathrm{kg}$ with a expense of $945 \mathrm{US} \$ / \mathrm{kg}$ enzyme while 99.77\% pureness biodiesel adopting catalyst as sodium hydroxide cost 0.77-1.31 US\$/kg [6]. Vegetable oils from variety sources commonly are glycerol tri-esters with distinct chain length. The primary solvent which commonly is 
used in the transesterification of glycerol tri-esters are mostly methanol. Ethanol \& amyl alcohol can be used too. Methanol is applied in this present work because it is easily available in the market and cost is low and have many advantages of chemical and physical properties also it can quickly react in transesterification process [7]. Base homogenous catalysts are used $(\mathrm{NaOH} \& \mathrm{KOH})$ where extreme conditions of pressure and temperature are not necessary [8]. Regular WVO (waste/ recycled vegetable oil/ cooking oil) consists of high free fatty acids (FFA) which causes serious barrier in transesterification process. The WVO can be administer to esterification process employing distinct acid catalysts but sulfuric acid catalyst transesterification process have been observed to be the best suited since the free fatty acid decreases up to $88.8 \%$ [9]. Use of WVO in biodiesel production will be beneficial for the devaluation of pollution and also a profitable extension of available energy in today's high energy demand [10]-[11]. Oil palm delivers the maximal yield of palm oil from a unit of biomass compare to most of the crops [12], also palm oil has turned into the second largest spend oil in global scale but at cheap price related to other comestible oils in the market [13]. Palm oil (POME) can be used in place of petroleum diesel. In the year of 2014, the government of Malaysia had mandated the adoption of 5\% palm biodiesel (B5 POME) with petroleum diesel in transport sector entire nationwide [14]. In 2018 researchers have claimed that industrial palm oil can yield sufficient biodiesel (POME) to effectively balance Malaysia's full diesel consumption. Diesel engine manufacturers provide engine warranties on consumption of biodiesel up to B7 in Malaysia and the fact that without any major modification diesel engine can handle biodiesel-diesel blends up to B100 (100\% biodiesel) can promise better future environment [15]. Araby et al. [16] estimated the important fuel requirements of Palm oil and POME blend with diesel and results indicate that blended fuel values were very adjacent to petroleum diesel till 30\% (B30). Equations are developed as a guide for adjudge the finest blending. Famous literature consistently indicates a heightened danger of coronary heart disease from palm oil which are enrich in 50\% \& $80 \%$ saturated fatty acids. In the year 2003, The World Health Organization reports that there is strong indication that palmitic oil intake add to a heightened danger of cardiovascular diseases [17]. This indicates in order to avoid that consequence, may be in future there will be production of palm oil as a bio-fuel source. Azadirachtaindica (neem) is contemplated as nonedible oil and accessible in excess quantities in the region of south asia [18], only in India the Annual production is reported about 30000tons. However due to immense FFA only transesterification is not very compelling to yield biodiesel from neem oil. To diminish FFA in NOME (neem oil methyl ester) 2 step transesterification (acid catalyzed esterification \& alkaline catalyzed transesterification) is being advised [19]. Biodiesel research in India is directed at nonedible oil like neem, mahua, castor, karanja etc. After reviewing all these background yielding of biodiesel from immense FFA neem oil and palm oil and the implementation as a feasible renewable fuel for unaltered diesel engine has been tested.

\section{BIODIESEL PRODUCTION EXPERIMENTAL SET-UP}

The experiment set up (Figure 1) consists of nine cylinders. Out of them, five are useful for the preparation of biodiesel. In the schematic diagram, in the lower part, out of three chamber the first chamber from the left is for catalyst, second one is for alcohol like methanol, ethanol and the last one is for mixing. These chambers are connected by pump which helps in pumping alcohol and catalyst to the main reactor cylinder. Also three valves are there to controls the flow. For the acceleration of chemical reaction, in the main reactor chamber fan is there that helps in proper mixing of reactant. Temperature sensors and controllers maintain required temperature inside the cylinder. Temperature control is essential for higher yielding and of minimum time requirement. Main reactor chamber is linked by a pump and valve to GC (glycerin column) chamber, here mixture remains for some time and due to different molecular weight, upper portion is filled with biodiesel and lower part with glycerol. At the base part of the GC (glycerin column) chamber, a valve is there that opens 
and glycerol comes out. Rest portion of the product that is biodiesel is taken later. Biodiesel at that time is not pure. Further purification is necessary.

Table 1: Properties of POME \& NOME

\begin{tabular}{|l|c|c|c|c|c|c|}
\hline Properties & $\begin{array}{c}\text { POME } \\
\text { (Experimental) }\end{array}$ & $\begin{array}{c}\text { NOME } \\
\text { (Experimental) }\end{array}$ & POME [16] & NOME [18] & ASTMD6751 & EN14214 \\
\hline Density & $898 \mathrm{Kg} / \mathrm{m}^{3}$ & $868 \mathrm{Kg} / \mathrm{m}^{3}$ & $877 \mathrm{Kg} / \mathrm{m}^{3}$ & $891 \mathrm{Kg} / \mathrm{m}^{3}$ & $\begin{array}{c}870-900 \mathrm{Kg} / \\
\mathrm{m}^{3}\end{array}$ & $\begin{array}{c}860-900 \\
\mathrm{Kg} / \mathrm{m}{ }^{3}\end{array}$ \\
\hline Viscosity & $\begin{array}{c}4.98 \mathrm{~mm}^{2} / \mathrm{s} \text { at } 40 \\
{ }^{\circ} \mathrm{C}\end{array}$ & $5.5 \mathrm{~mm}^{2} / \mathrm{s}$ at $40{ }^{\circ} \mathrm{C}$ & $\begin{array}{c}4.56 \mathrm{~mm}^{2} / \mathrm{s} \\
\text { at } 40{ }^{\circ} \mathrm{C}\end{array}$ & $\begin{array}{c}6.16 \mathrm{~mm}^{2} / \mathrm{s} \\
\text { at } 40{ }^{\circ} \mathrm{C}\end{array}$ & $1.9-6.0 \mathrm{~mm}^{2} / \mathrm{s}$ & $\begin{array}{c}3.5-5.0 \\
\mathrm{~mm}^{2} / \mathrm{s}\end{array}$ \\
\hline $\begin{array}{l}\text { Flash } \\
\text { Point }\end{array}$ & $179.33{ }^{\circ} \mathrm{C}$ & $175{ }^{\circ} \mathrm{C}$ & $196{ }^{\circ} \mathrm{C}$ & - & $>130{ }^{\circ} \mathrm{C}$ & $>120{ }^{\circ} \mathrm{C}$ \\
\hline $\begin{array}{l}\text { Calorific } \\
\text { Value }\end{array}$ & $37.06 \mathrm{MJ} / \mathrm{Kg}$ & $36.04 \mathrm{MJ} / \mathrm{Kg}$ & $41.3 \mathrm{MJ} / \mathrm{Kg}$ & $\begin{array}{c}39.87 \mathrm{MJ} / \\
\mathrm{Kg}\end{array}$ & - & - \\
\hline
\end{tabular}

For that washing should be done repeatedly with water until $\mathrm{PH}$ value of water comes to 7. Alkaline transesterification is used to produce POME from palm oil and free fatty acid (FFA) is less than 6.1\% [20]. A 2 step transesterification (acid catalyzed esterification \& alkaline catalyzed transesterification) process is used to produce NOME from neem oil and free fatty acid (FFA) is 6.16\%.In the experimental set-up main reactor; raw oil is loaded with the mixture of methanol and $\mathrm{KOH}$ in the $6: 1$ ratio. raw oil reacts with methanol in presence of catalyst to produce NOME \&POME and glycerol at $55^{\circ} \mathrm{C}$.

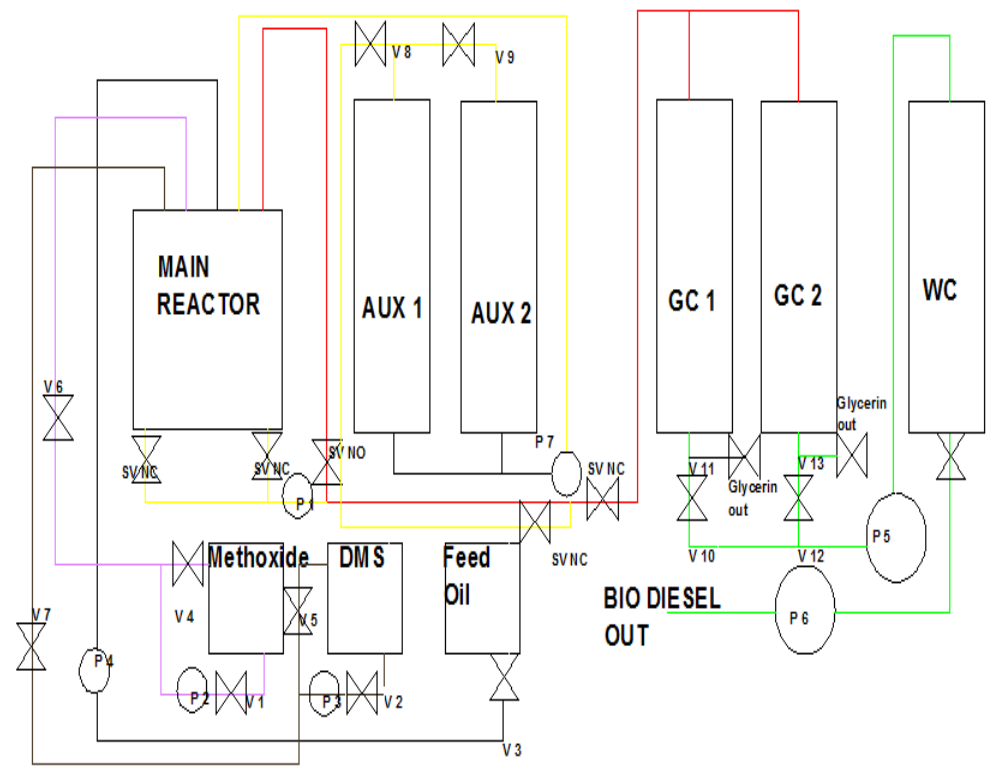

Figure 1.Biodiesel Production Experimental Set-Up

\section{RESULTS \& DISCUSSIONS}

The performance characteristics of B5 and B10 (NOME \& POME) fuels blends have been tested in a single-cylinder (661.45cc), four-stroke, direct-injection, compression-ignition engine (3.50 kW @ 1500) experimental setup coupled with a dynamometer (TMEC10). A piezoelectric pressure sensor (Model S111A22) is used to measure in-cylinder pressure. All the temperature and pressure data are collected in a data acquisition panel (NI USB-6210) and monitored from the computer software program. 18:1 compression ratio is used for this study. Table 1 indicates that the properties of produced biodiesel (NOME \&POME) are comparable with the biodiesel American standards ASTM D 6751 and European standards 
EN 14214.Performance characteristics among B0 (diesel), B5NOME, B5 POME, B5n5(5\% POME with 5\% 1- Butanol) and B5E5 (5\% POME with 5\% Diethyl ether)has been made at different loads. Relevant engine performance criterion like BTE (brake thermal efficiency) (figure 2) and SFC (brake specific fuel consumption) (figure 3) have been examined at various loads at $1500 \mathrm{rpm}$. Also performance characteristics among B0 (diesel), B10 NOME, B10POME, B10n10 (10\% POME with 10\% 1- Butanol) and B10E10 (10\% POME with 10\% Diethyl ether) has been made at different loads (figure 4 \& figure 5).

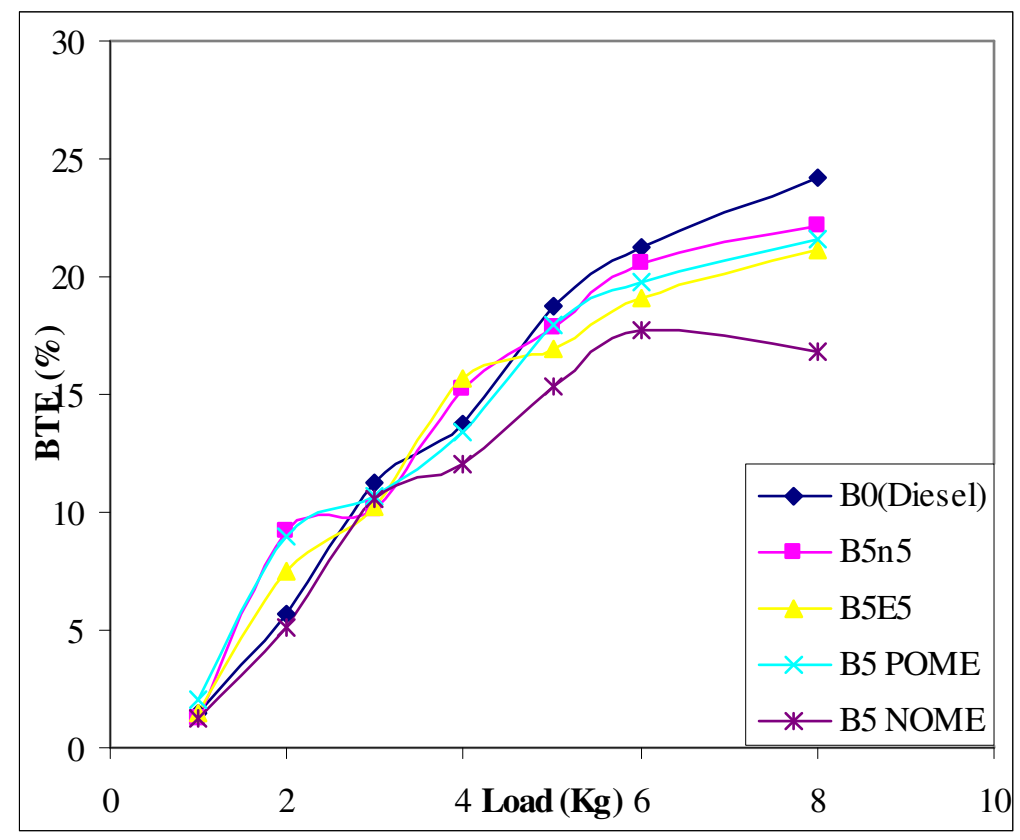

Figure 2: Graphical Illustration of BTE at Different Loading.

In considerable previous works [18], [21] combustion quality had been indicated with brake thermal efficiency which is proportional to load on engine [22]. It was observed that BTE for NOME \& POME B5 blends was higher than petroleum diesel at low load conditions (20\%-30\%) because of oxygenated fuel, but for NOME \& POME B10 blends it was decreased because of high viscosity, poor atomization and low heating value of biodiesel [18]. Also for additives with POME blends, 5\%-10\% Diethyl ether and 1-Butanollow BTE was detected cause of evaporation effect which resulted poor performance against diesel.

Experiment shows that (figure 2) in case of BTE at 75\% Load condition there are $30.65 \%$ decreases for B5 NOME, 10.79\% decreases for B5 POME, 8.35\% decreases for B5n5 (5\% POME with 5\% 1- Butanol) and 12.61\% decreases for B5E5 (5\% POME with 5\% Diethyl ether). 


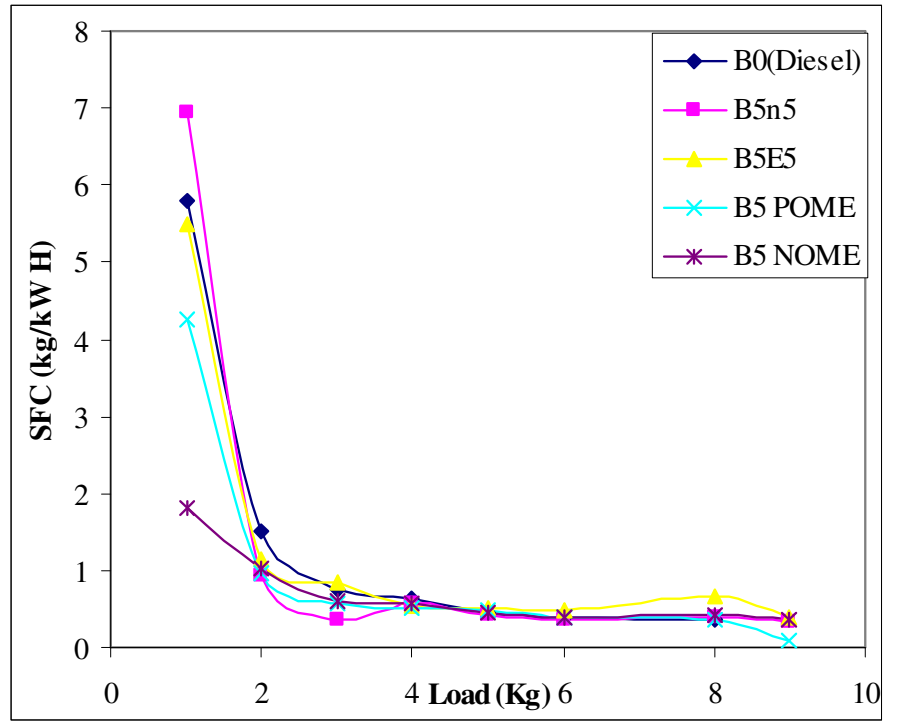

Figure 3: Graphical Illustration of BSFC at Different Loading.

Also, in case of BTE at 75\% Load condition (figure 4) there are 30.86\% decreases for B10 NOME, $7.15 \%$ decreases for B10 POME, 26.89\% decreases for B10n10 (10\% POME with 10\% 1- Butanol) \& B10E10 (10\% POME with $10 \%$ Diethyl ether), though at 50\%Load condition the differences among B0 (Diesel) and biodiesel blends are very slick and at low load condition the BTE results are very auspicious for biodiesel blends. figure (3) and figure (5) reveals that at high load conditions BSFC is higher for biodiesel blends compared to B0(Diesel) but at low load BSFC for biodiesel blends are compatible with petroleum diesel.

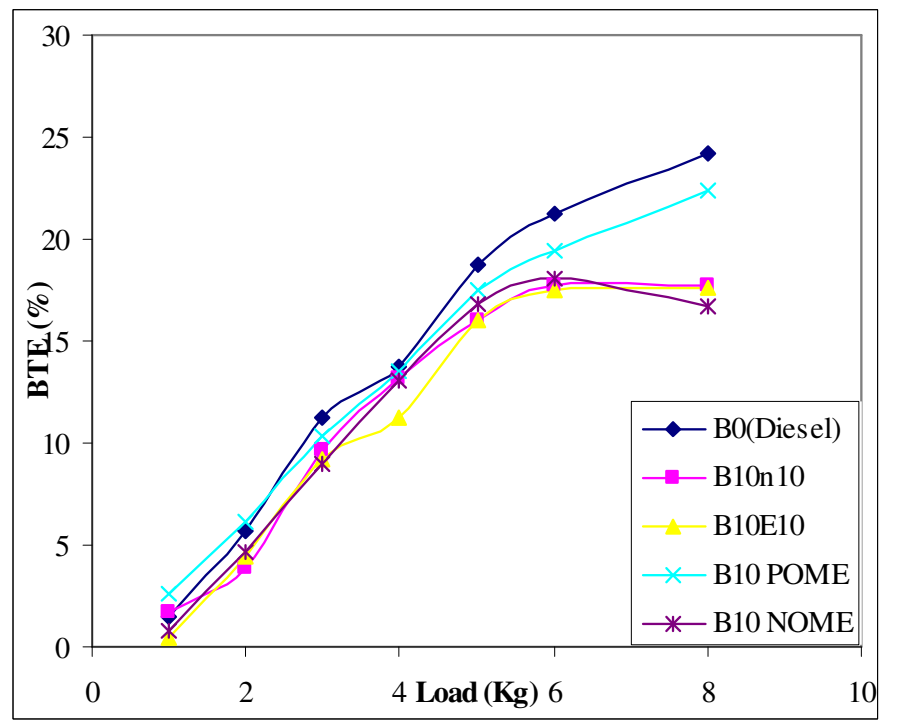

Figure 4: Graphical Illustration of BTE at Different Loading. 


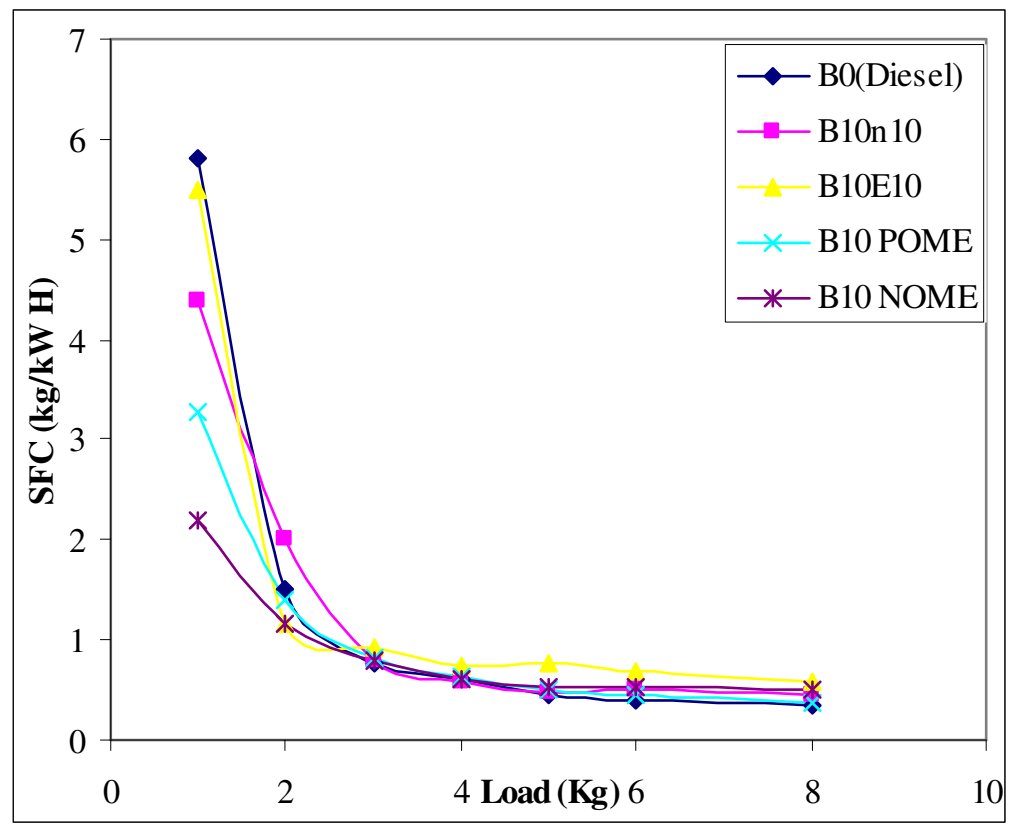

Figure 5: Graphical Illustration of BSFC at Different Loading.

\section{CONCLUSIONS}

In this study, it has been found out that Neem Oil \& Palm oil could be a sustainable source of NOME \&POME biodiesel. Optimization has been done to increase the production and maintain the quality of biodiesel. Optimum yielding of biodiesel is about $69 \%$ for NOME and $81.45 \%$ for POME when the average heating value is about $36.04 \mathrm{MJ} / \mathrm{Kg}$ for NOME and37.06MJ/Kg for POME. The performance study indicates that NOME \&POME biodiesel blends B5 \& B10 can be used to reinstate petroleum diesel at low engine load conditions. Although there are concerns regarding poor performance criterion at high engine loads. The viscosity variation, poor atomization and low heating value of fuel in NOME \&POME blends affects the performance quality for B5 and B10 blends. Results reveal that quality of performance the sink around $30 \%$ for NOME \& 10\% for POME compared to petroleum diesel fuel in terms of BTE (brake thermal efficiency). Also, addition of 1- Butanol and Diethyl ether in small batch (5\% \&10\%) with POME blends has no greater effect in terms of engine performance. At full load condition Brake specific fuel consumption (BSFC) of biodiesel blends looks steep when compared with petroleum diesel.

\section{REFERENCES}

1. H. C. Ong, T. M. I. Mahlia, H. H. Masjuki, R. S. Norhasyima, "Comparison of palm oil, Jatropha curcas and Calophylluminophyllum for biodiesel: A review”. Renewable and Sustainable Energy Reviews (2011). 15, 3501-3515.

2. J. Janaun, N. Ellis, “Perspectives on biodiesel as a sustainable fuel”. Renewable \& Sustainable Energy Reviews (2010). 14, $1312-20$

3. A. M. Hupp, J. Perronb, N. Roquesb, J. Crandallb, S. Ramosc, B. Rohrbackc, "Analysis of biodiesel-diesel blends using ultrafast gas chromatography (UFGC) and chemometric methods: Extending ASTM D7798 to biodiesel”. Fuel (2018). 231, $264-270$.

4. H. Chen, B. Xie, J. Ma, Y. Chen, "NOx emission of biodiesel compared to diesel: Higher or lower?". Applied Thermal Engineering (2018). 137, 584-593. 
5. Ayoola, A. A., et al. "Comparison Of The Properties Of Palm Oil And Palm Kerneloil Biodiesel In Relation To The Degree Of Unsaturation Of Their Oil Feedstocks." International Journal of Applied And Natural Sciences 5.3 (2016): 1-8.

6. M. Balat, H. Balat, "A critical review of bio-diesel as a vehicular fuel". Energy Conversion and Management (2008). 49, $2727-41$.

7. T. A. Andrade, M. Martín, M. Errico, K. V. Christensen, "Biodiesel Production Catalyzed by Liquid and Immobilized Enzymes:Optimization and Economic Analysis. Chemical Engineering Research and Design”. https://doi.org/10.1016/j.cherd.2018.10.026.

8. J. Krishnakumar, V. S. K. Venkatachalapathy, S. Elancheliyan, "Technical Aspects of Biodiesel Production from Vegetable Oils”. Thermal Science (2008). 12, 159-169.

9. Srikanth, D., et al. "Performance exhaust emissions, and combustion characteristics of cotton seed oil based biodiesel in ceramic coated diesel engine." International Journal of Mechanical Engineering 2.5 (2013): 67-82.

10. A. K. Agarwal, "Biofuels (alcohols and biodiesel) applications as fuels for internal combustion engines". Progress in Energy and Combustion Science (2007). 33, 233-271.

11. S. S. Sahar, J. Iqbal, I. Ullah, H. N. Bhatti, S. Nouren, H. Rehman, J. Nisar, M. Iqbal, "Biodiesel production from waste cooking oil: An efficient technique to convert waste into biodiesel”. Sustainable Cities and Society (2018). 41, 220-226.

12. Hymavathi, D., G. Prabhakar, and B. B. Sarath. "Biodiesel production from vegetable oils: an optimization process." Int J Chem Petrochem Technol, 4 (2), 2130 (2014).

13. M. Arshad, I. Bano, N. Khan, M. I. Shahzad, M. Younus, M. Abbas, "Electricity generation from biogas of poultry waste: An assessment of potential and feasibility in Pakistan”. Renewable and Sustainable Energy Reviews (2018). 81, 1241-1246.

14. A. Tangy, I. N. Pulidindi, A. Gedanken, "SiO2 beads decorated with SrO nanoparticles for biodiesel production from waste cooking oil using microwave irradiation”. Energy and Fuels (2016). 30, 3151-3160.

15. M. Koushki, M. Nahidi, F. Cheraghali, "Physico-chemical properties, fatty acid profile and nutrition in palm oil". Journal of Paramedical Sciences (2015). Vol.6, No.3 ISSN 2008-4978. https://doi.org/10.22037/jps.v6i3.9772.

16. Bhaskar, K., et al. "Effect of dimethoxy-methane (C3H8O2) additive on emission characteristics of a diesel engine fueled with biodiesel." International Journal of Mechanical and Production Engineering Research and Development 8.1 (2018): 399-406.

17. B. M. Siddique, M. H. Ibrahim, S. Hena, "Physicochemical properties of blends of palm oil with other vegetable oils". Grasas Y Aceites(2010). 61, 423-429. doi: 10.3989/gya.010710.

18. H. Adnan, "Palm oil biodiesel programme to cover all of Malaysia by July". The star online; (2014). https://www.thestar.com.my/business/business-news/2014/04/26/b5-goes-nationwide/ (accessed 4 February 2019).

19. K. R. Szulczyk, A. R. Khan, "The Potential and Environmental Ramifications of Palm Biodiesel: Evidence from Malaysia". Journal of Cleaner Production (2018). doi:10.1016/j.jclepro.2018.08.241.

20. R. Araby, A. Amin, A. K. Morsi, N. N. Ibiari, G. I. Diwani,. "Study on the characteristics of palm oil-biodiesel-diesel fuel blend". Egyptian Journal of Petroleum (2018). 27, 187-194.

21. S. Mukherjee, and A. Mitra, "Health Effects of Palm Oil". Journal of human ecology (2009). 26, 197-203.

22. A. Dhar, R. Kevin, A. K. Agarwal, "Production of biodiesel from high-FFA neem oil and its performance, emission and combustion characterization in a single cylinder DICI engine”. Fuel Processing Technology 97 (2012) 118-129. 
23. M. C. Sekhar, V. R. Mamilla, M. V. Mallikarjun, V. K. Reddy, "Production of Biodiesel from Neem Oil”. International Journal of Engineering Studies ISSN 0975- 6469 Volume 1, Number 4 (2009), pp. 295-302.

24. H. J. Berchmans, S. Hirata, "Biodiesel production from crude Jatropha curcas L. seed oil with a high content of free fatty acids”. Bioresource Technology (2008). 99, 1716-1721.

25. M. Das, M. Sarkar, A. Datta, A. K. Santra, "An experimental study on the combustion, performance and emission characteristics of a diesel engine fuelled with diesel-castor oil biodiesel blends". Renewable Energy (2018). 119, 174-184.

26. G. Goga, B. S. Chauhan, S. K. Mahla, H. M. Cho, "Performance and emission characteristics of diesel engine fueled with rice bran biodiesel and n-butanol”. Energy Reports (2019). 5, 78-83.

\section{AUTHORS POOFILES}

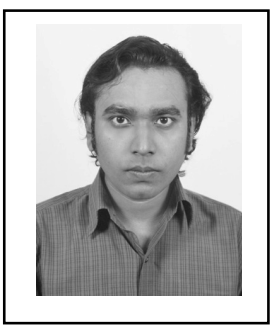

Abhishek Samanta, Lecturer in Automobile Engineering, Ranaghat Govt. Polytechnic \& Ph.D. scholar, Jadavpur University.

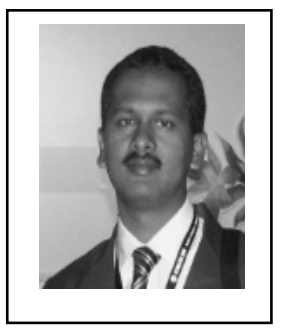

Dr. Prokash C. Roy, Associate Professor, Department of Mechanical Engineering, Jadavpur University. 